\title{
Effect of Soil Temperature, Moisture and pH on Soil L-glutaminase Activity
}

\author{
G. Pavani* , P. Chandrasekhar Rao, G. Padmaja and B. Naveen Kumar \\ Department of Soil Science and Agricultural Chemistry, College of Agriculture, \\ Professor Jayashankar Telangana State Agricultural University, Rajendranagar, \\ Hyderabad - 500030, Telangana, India \\ *Corresponding author
}

\begin{tabular}{|c|c|}
\hline & A B S T R A C T \\
\hline & The experiment was carried out in the department of soil science and agricultural \\
\hline Keywords & (L-glutamine amido hydrolase E.C. 3.5.1.2) cause the hydrolysis of L-glutamine to \\
\hline $\begin{array}{l}\text { L-glutaminase, } \\
\text { Temperature, } \\
\text { pH, Moisture, } \\
\text { Enzyme activity. }\end{array}$ & $\begin{array}{l}\text { ammonia, L-glutamic acid, thus it makes the amide form of nitrogen avallable to the } \\
\text { plants. We have detected this enzyme in soils. A simple, precise, rapid and sensitive } \\
\text { method was used to assay its activity which involves determination of the } \mathrm{NH}^{+} \text {released } \\
\text { by l-glutaminase activity when soil is exposed to l-glutamine, Tris (hydroxymethyl) } \\
\text { aminomethane (THAM) buffer and toluene at } 37^{\circ} \mathrm{C} \text { for } 2 \mathrm{~h} \text {. The } \mathrm{NH}^{+}{ }_{4}^{-} \mathrm{N} \text { released is }\end{array}$ \\
\hline Article Info & determined by treatment of the soil sample with $2.5 \mathrm{~m} \mathrm{KCl}$ containing a l-glutaminase \\
\hline $\begin{array}{l}\text { Accepted: } \\
\text { 26 June } 2017 \\
\text { Available Online: } \\
10 \text { August } 2017\end{array}$ & $\begin{array}{l}\text { effect of moisture, } \mathrm{pH} \text {, and temperature on L-glutaminase activity. The results showed that } \\
\text { the optimum temperature, moisture, } \mathrm{pH} \text {, for L-glutaminase activity was at } 50^{\circ} \mathrm{C}, 50 \%, \mathrm{pH} \\
\text { of } 8 \text { respectively. The optimum conditions were suitable for enzyme activity, any deviation }\end{array}$ \\
\hline & from these optimum conditions were led to lower in enzyme activity. \\
\hline
\end{tabular}

\section{Introduction}

Glutamine is widely distributed in plants, animal and microorganisms. It has two forms, $\mathrm{L}$ and $\mathrm{D}$ forms. Among these L- Isomer is predominant in nature. The enzyme glutaminase has stereo specificity in L and D isomers of glutamine. L-Glutamine plays a major role in nitrogen translocation and storage in many plants. This amino acid seems to be involved in the mineralization of nitrogen stored in lupin seeds. In many legumes and oil seeds, L-glutamine and Lasparagine are the main assimilatory products of nitrogen fixation (Atkins et al., 1975). Plants may contribute substantial amount of L-glutamine in soil by the action of L- glutaminase release ammonium to the inorganic nitrogen pool. Every enzyme shows maximum activity at an optimum $\mathrm{pH}$, temperature and moisture, if there was any deviation from these optimum ranges makes the enzymes inactive.

There are two aspects to the temperature sensitivity of enzymes. The first aspect is their thermal stability or their ability to maintain their structure across a range of temperatures. The second aspect is the temperature sensitivity of catalytic activity, which is determined primarily by the accessibility of the active site of the enzyme 
(Wallenstein et al., 2011). The temperature needed to inactivate the same enzyme in soils is about $10-15^{\circ} \mathrm{C}$ higher than the temperature needed to inactivate the same enzyme in the absence of soil. L-glutaminase in soils was assayed at $37^{\circ} \mathrm{C}$ because this temperature has been used extensively for assay of other soil enzymes. Change in $\mathrm{H}^{+}$ion concentration influence enzymes, substrate and cofactors by altering their ionization and solubility. Variation in such properties on ionization and solubility influence the rate of catalyzed reactions. Enzyme being proteinaceous, exhibits marked changes in ionization from fluctuations in $\mathrm{pH}$. Characteristically each enzyme has a $\mathrm{pH}$ value at which the rate is optimal and either side of this optimum the rate is lower, thus the catalytic action of the enzyme operates in a some restricted $\mathrm{pH}$ range. Enzymes are usually most stable in the vicinity of optimum $\mathrm{pH}$. Studies on effect of $\mathrm{pH}$ on soil enzymes are important because, exposure to extreme $\mathrm{pH}$ values may irreversibly inactivates enzymes that play an essential role in nutrient $(\mathrm{N}, \mathrm{P}$ and $\mathrm{S})$ transformation and humus formation. The hydrogen ion concentration of soils can vary considerably, most soils range between four and eight.

Studies of the effect of buffer on enzymecatalyzed reactions are essential because hydrogen ion concentration in the reaction system affects the ionization groups of enzyme proteins and influences the ionization state of the substrate. The ionizable groups of both enzyme and substrate must be in their proper states to maintain the conformation of the enzyme active sites to bind with the substrate and thus catalyze the reaction. The most usual type of $\mathrm{pH}$-activity relationship found for enzymes is a bell-shaped curve. The soil pH 10 was reported by Frankenberger and Tabatabai (1991b) for the assay of Lglutaminase in soils. A choice however exists to measure the enzyme activities at the actual
$\mathrm{pH}$ of the field soils so that the activity under field conditions are measured rather than actual potential activity of enzymes in soil. According to Frankenberger and Tabatabai (1980) the optimum $\mathrm{pH}$ observed for amidase activity $(\mathrm{pH}=8.5)$ was somewhat higher than that $(\mathrm{pH} 6.5)$ reported for amidase activity of Pseudomonas fluorescent isolated from a garden soil (Jakoby and Fredericks, 1964). This deviation in $\mathrm{pH}$ optimum for amidase activity in solution from that in soils is expected because it is well known that the $\mathrm{pH}$ optima of enzymes in solutions are about 2 $\mathrm{pH}$ units lower than the same enzymes in soils. Omura et al., (1983) reported that the Lglutaminase activity was estimated on five soil samples different in $\mathrm{pH}$, organic-C content and vegetation and observed that the optimum $\mathrm{pH}$ of the L-glutaminase activity was at about 7.5-7.8.

\section{Materials and Methods}

\section{Effect of temperature on L-glutaminase activity}

Effect of temperature on the activity of Lglutaminase was assayed in selected Alfisols and Vertisols using duplicate samples. To 10 $\mathrm{g}$ of soil sample in a $150 \mathrm{ml}$ conical flask, 12 $\mathrm{ml}$ of $0.1 \mathrm{M}$ THAM (pH 8) and $8 \mathrm{ml}$ of 0.125 $\mathrm{M} \mathrm{L}$-glutamine were added and incubated in a constant water bath at temperatures of 20, 30, $40,50,60,70,80 \pm 5^{\circ} \mathrm{C}$. After 2 hours of incubation the enzyme activity was assayed by steam distillation method (Frankenberger and Tabatabai, 1991)

\section{Determination of L-glutaminase activity at different moisture levels pre incubated with water under aerated condition}

To study the effect of moisture levels on the activity of L-glutaminase. To $10 \mathrm{~g}$ of selected soils, two Vertisols (VS 1and VS 2) and two Alfisols (AS 1 and AS 2), pre-determined 
values of distilled water, THAM $(0.1 \mathrm{M})$ and substrate $(0.125 \mathrm{M})$ were added, such that the soil moisture varied from 10 to $100 \%$. These were incubated at $37 \pm 0.5^{\circ} \mathrm{C}$, and were assayed for the activity of L-glutaminase. The rate of $\mathrm{NH}_{4}{ }^{+}$released was estimated by steam distillation method. The soil moisture content for Alfisols was 20 to $25 \%$ and for the Vertisols it ranges from 30 to $45 \%$.

\section{Effect of pH on L-glutaminase activity}

The effect of $\mathrm{pH}$ on L-glutaminase activity was studied in four selected soils by adding $12 \mathrm{ml}$ of $0.1 \mathrm{M}$ THAM buffer with $\mathrm{pH}$ varying from 2 to 10 . The $\mathrm{pH}$ of THAM buffer was adjusted by using $0.1 \mathrm{~N} \mathrm{HCl}$ or 0.1 $\mathrm{N} \mathrm{NaOH}$ depending on $\mathrm{pH}$ required. The substrate L- glutamine of $0.125 \mathrm{M}$ was also prepared in the corresponding THAM buffer. The rate of $\mathrm{NH}_{4}{ }^{+}$released was estimated by steam distillation method (Frankenberger and Tabatabai, 1991).

\section{Results and Discussion}

\section{Effects of Temperature on soil L- glutaminase}

Temperature is an important factor affecting enzyme catalysed reactions. Enzymes have an effective range and an optimal temperature of operation i.e., determined by their size and composition at low temperature. The enzyme or the matrix with which they are associated freeze at temperatures only a few degrees above their optimum. The tertiary structure of the enzyme begins to denature, unless it is stabilized by interactions with particle surfaces or humic complexes (Wallenstein et al., 2011). The results pertain to the effect of temperature on L-glutaminase activities are presented in figure 1 .

The L-Glutaminase activity of all the soils increased with increase in temperature from
20 to $50^{\circ} \mathrm{C}$ and then decreased rapidly with further increase in temperature up to $80^{\circ} \mathrm{C}$. This is in good agreement with that reported from L-Asparaginase in Bacillus coagulans (Law and Wriston, 1971) and also Iowa soils for L-glutaminase by Frankenberger and Tabatabai (1991c). Denaturation occurs beyond $60^{\circ} \mathrm{C}$ which is similar to that reported for amidase (Frankenberger and Tabatabai, 1980) Arylsulfatase (Tabatabai and Bremner, 1970). The optimal temperature for Lglutaminase was found to be approximately $10^{\circ} \mathrm{C}$ lower than that of L-asparaginase (Frankenberger and Tabatabai 1991c). It is a known fact that the temperature needed to inactivate enzymes in soils is about 10 to 15 degrees higher than the temperature needed to inactivate the same enzyme in the absence of soil (Tabatabai, 1982; Reddy and Chhonkar, 1991; Tarafdar and Chhonkar, 1978; Rao et al., 1989). Vandana (2012) also reported similar findings for soil urease and phosphatases. This has been generally attributed to the immobilization of soil enzymes on soil colloids and cell debris. Presumably this helps them to retain their conformation and structure intact over higher temperature intervals.

\section{Effect on soil moisture on soil L- glutaminase activity}

The results on the effects of varying the moisture from 20 to $100 \%$ on L-glutaminase activity in the selected soils are depicted graphically in figure 2 . The results show that the activity of L-glutaminase increased with increased moisture levels from $30 \%$ to $100 \%$ but a sharp increase was observed up to $50 \%$ moisture and there after it levels down. Such results were reported for urease activity (Rao, 1989; Vandana, 2012) therefore it could be observed that moisture may not be constant in well drained soils. Whereas the effect of moisture on soil L-glutaminase may be crucial for dryland agriculture where the 
moisture content is often less than field conditions, under these conditions Lglutaminase activity may be too low for effective mineralization of glutaminase nitrogen. Sharawat (1984) showed that urease activity increased with increase in moisture from air dried to field capacity and recorded no change with further increase in moisture. Sardans and Penuclas (2010) studied the effect of drought on soil enzyme activity. Soils when subjected to runoff plus partial rainfall elimination results in the reduction of enzyme activity by $25 \%$. The decline in enzyme abundance and its potential activity is due to decline in soil enzyme accumulation during prolonged drought which in turn causes decrease in soil organic carbon, substrate quality, change in $\mathrm{C}: \mathrm{N}$ ratio and hence, effecting microbial enzyme production. Thus, it is observed that the soil moisture exerts profound influence on soil enzyme production and nutrient availability. Tripathi et al., (2008) observed that population of various microorganisms and activity of soil enzymes like dehydrogenase and phosphatase have been reduced significantly with the use of contaminated waste water for irrigation, mainly due to buildup of salinity and significant increase in $\mathrm{pH}, \mathrm{EC}$ and accumulation of toxic elements.

Fig.1 Effect of Temperature on soil L- glutaminase activity

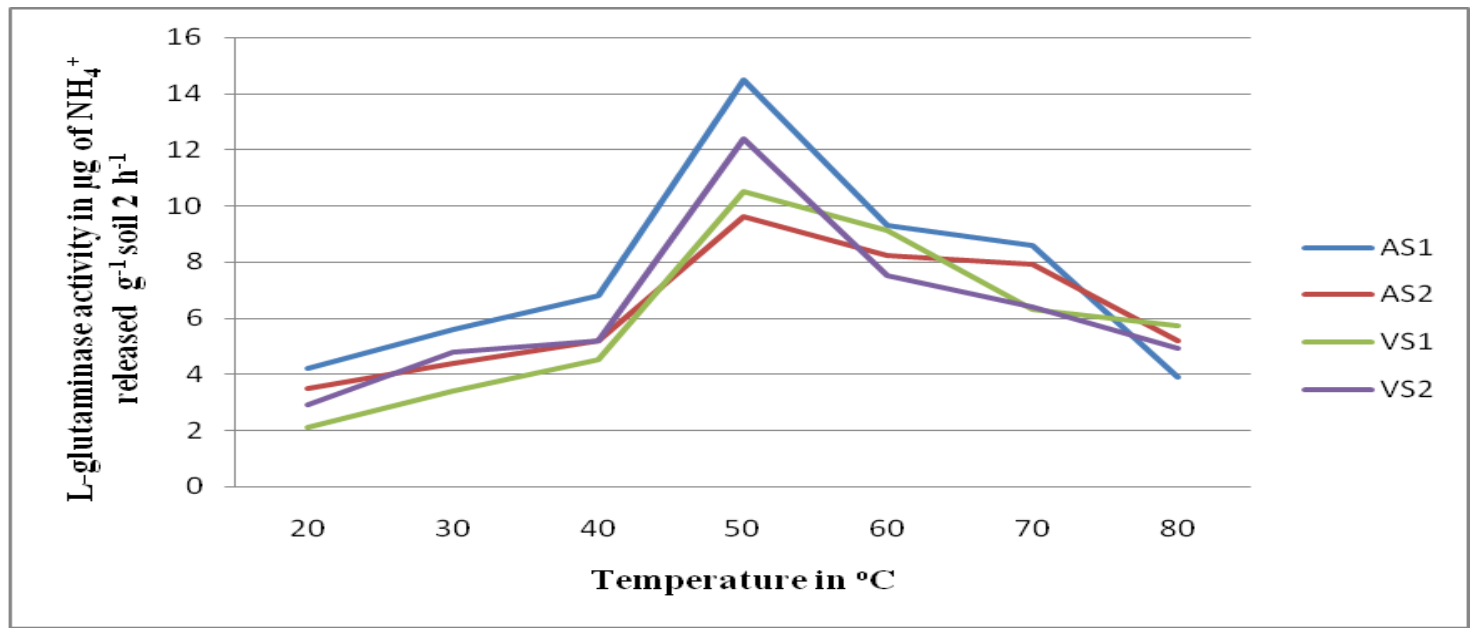

Fig.2 Effect of Moisture on soil L-glutaminase activity

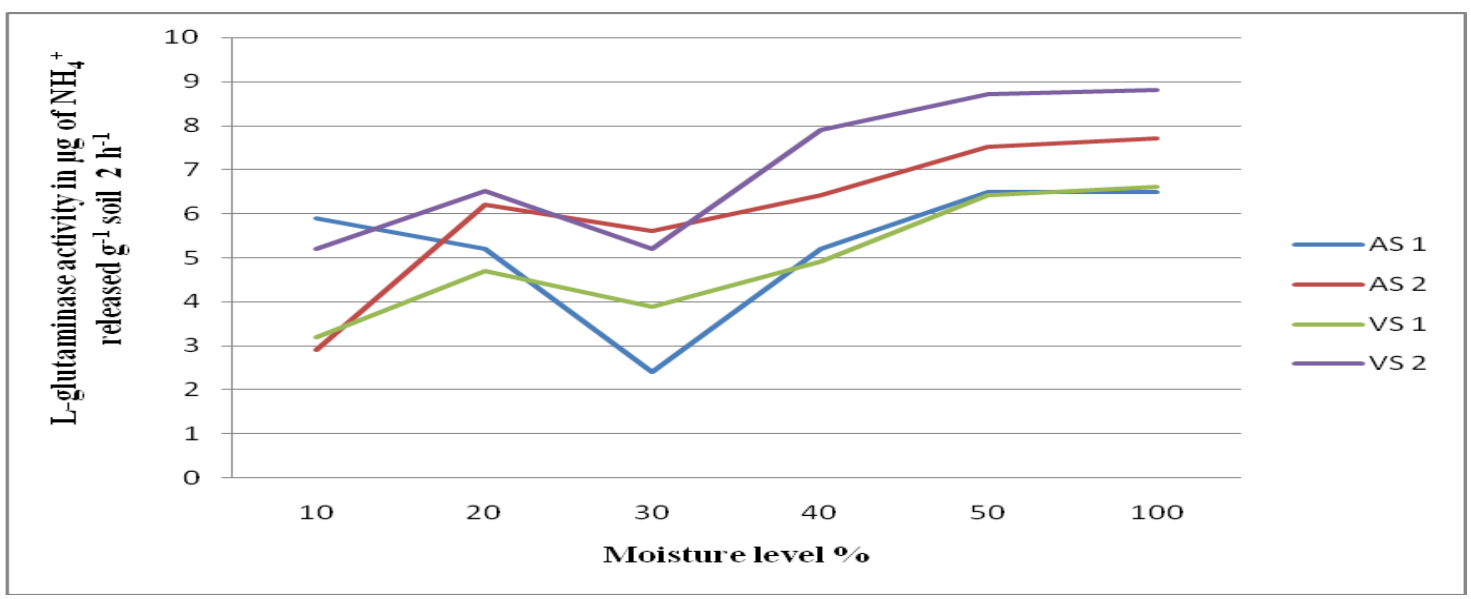


Fig.3 Effect of pH on Soil L-glutaminase activity

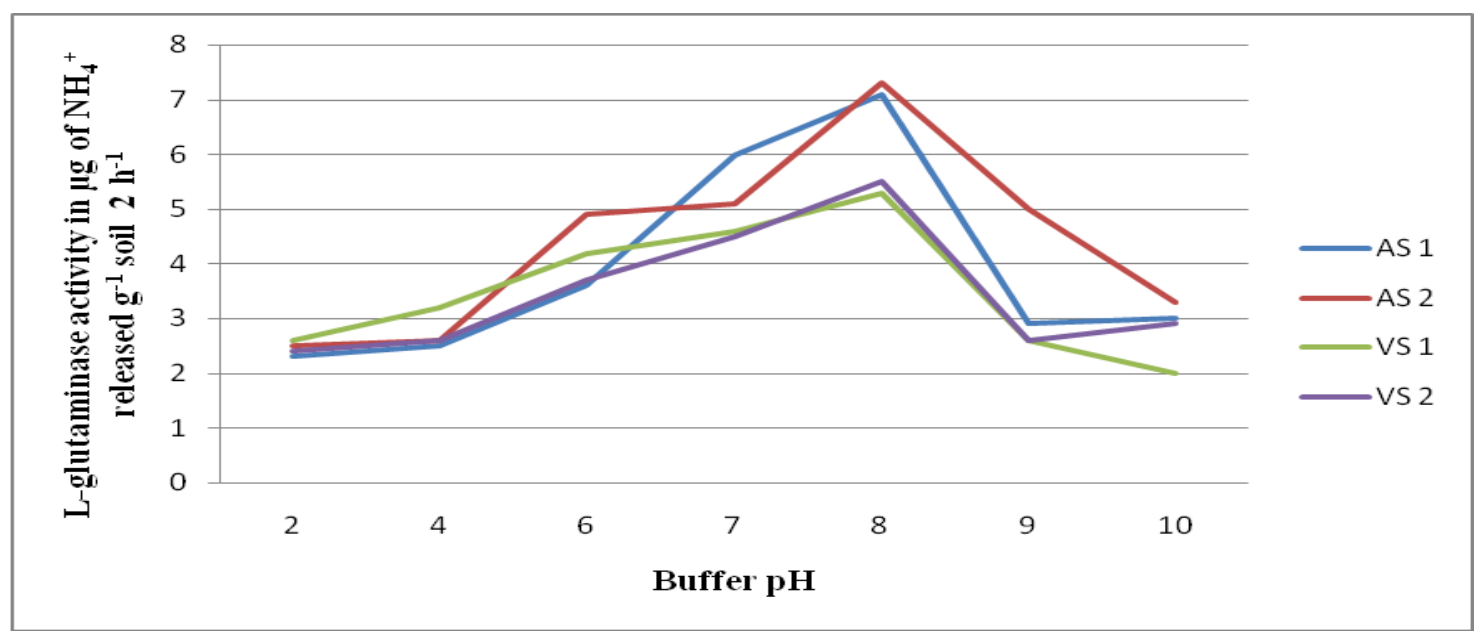

\section{Effect of pH on soil L-glutaminase activity}

The results pertaining to effect of $\mathrm{pH}$ in the range of 2 to 10 maintained with THAM buffer, on the activity of L-glutaminase is depicted in figure 3. The L-glutaminase activity in all the soils increased till about $\mathrm{pH}$ 8 and then decreased later. Different soils exhibited slightly different values. Similar results were obtained by Tabatabai and Bremner (1982), Srinivas (1993) and Vandana (2012). When the soil enzymes are exposed to extreme acid and alkaline conditions the catalytic activity of enzyme protein decreased probably because of $\mathrm{pH}$ effects on over all three dimensional structure of protein itself. Exposure to high $\mathrm{H}^{+}$and $\mathrm{OH}^{-}$ ion concentration tends to disrupt ionic and hydrogen bonds needed to maintain the active conformation of the enzyme resulting in loss of biological activity. The $\mathrm{pH}$ of soil solution exerts a strong control on the enzyme activity because it influences the conformation of enzyme, its absorption on solid surfaces ionization and the solubility of substrates and co-factors (Turner, 2010; Frankenberger and Johanson, 1982) indicated that the variation in pH stability of enzymes was due to different sources contributing to enzyme activity and to adsorption properties of soils themselves. In a study conducted by Shi et al., (2008) it was found that soil $\mathrm{pH}$ had a negative effect on urease and phosphatase activity but the effect was counteracted by the positive indirect effect of soil organic matter. Omura et al., (1983) reported that the L-glutaminase activity was estimated on five soil samples different in $\mathrm{pH}$, organic carbon content and vegetation. And found that the optimum $\mathrm{pH}$ of the L-glutaminase activity was at about 7.5-7.8. Soda et al., (1966) reported that the optimum $\mathrm{pH}$ value for the activity of Lglutamine hydrolase which was purified from P. aeruginosa ranged from 8.5 to 9.0. On the other hand, the optimum $\mathrm{pH}$ of the enzymes from E. coli and Azotobacter agilis were in the range from 5.0 to 5.5 and from 6.0 to 7.0 respectively.

In conclusion, L-Glutamine enzyme plays a major role in nitrogen translocation and storage in many plants. This amino acid seems to be involved in the mineralization of nitrogen. The L-Glutaminase activity of all the soils increased with increase in temperature from 20 to $50^{\circ} \mathrm{C}$ and then decreased rapidly with further increase in temperature up to $80^{\circ} \mathrm{C}$. L-Glutaminase activity was maximum at temperature $50{ }^{\circ} \mathrm{C}$, beyond and above this temperature it shows denature of the enzyme activity. The results show that the activity of L-glutaminase 
increased with increased moisture levels from $30 \%$ to $100 \%$ but a sharp increase was observed up to $50 \%$ moisture and there after it levels down. The optimum moisture for this enzyme is at $50 \%$ moisture.

L-glutaminase activity in soils exhibited high activity at $\mathrm{pH} 8$ as compared to $\mathrm{pH} 10$. This is because of apparent $\mathrm{pH}$ optimum for clay observed enzymes is generally displaced 1 or $2 \mathrm{pH}$ units more to the alkaline values. This shift in $\mathrm{pH}$ optimum to higher values occurs because of the Bronsted acidity at clay surface is significantly greater than in bulk solution. At this suitable temperature, $\mathrm{pH}$ and moisture this enzyme perform highest activity.

\section{References}

Atkins, G.A., Pate, J.S and Sharkey, P.J. 1975. Asparagine metabolism - key to the nitrogen nutrition of developing legume seeds. Plant Physiology. 56: 807-812.

Frankenberger, W. T., Jr and Tabatabai M. A. 1991 a. Factors affecting L-glutaminase activity in soils. Biology and Fertility of Soils. 11. 1-5.

Frankenberger, W.T., Jr and Tabatabai, M.A. 1980. Amidase activity in soils: I. Method of assay. Soil Science Society of America Journal. 44: 282-287.

Frankenberger, W.T., Jr and Tabatabai, M.A. 1991b. L-asparaginase activity of soils. Biology and Fertility of Soils. 11: 6-12.

Frankenberger, W.T., Jr and Tabatabai, M.A. 1991c. L-Glutaminase activity of soils. Soil Biology \& Biochemistry. 869-874.

Law, A.S., and Wriston, J.C. Jr 1971. Purification and properties of Bacillus coagulans L-asparaginase. Archives of Biochemistry and Biophysics. 147: 744752.

Omura, H., Sato, F. and Hayano, K. 1983. A method for estimation of L-glutaminase activity in soils. Soil Science and Plant
Nutrition. 29 (3): 295-303.

Rao, P.C., Raman, S and sankar rao, V. 1989. Urease activity in soils. Paper presented at 54th Annual Convention of Indian Society of Soil Science held at Orissa. University of Agricultural Technology Bhuvaneshwar. Nov 1989.

Reddy, S.M., and Chhonkar, P.K. 1991. Urease activity in soil and flood water as influenced by regulatory chemicals and oxygen stress. Journal of Indian Society of Soil Science. 39: 84-88.

Sallis, P. J., and Burns, R.G. 1989. The Characterization of Amidohydrolases in a Freshwater Lake Sediment. Microbial Ecology. 17: 159-170.

Sardans, J., and Penuelas, J. 2010. Drought decreases soil enzyme activity in a Mediterranean Quercus ilex L. Forest. Soil Biology and Biochemistry. 37: 455461.

Shi, Z.J., Lu, Y., Xu, Z.G and Fu, S.L. 2008. Enzyme activities of urban soils under different land use in the Shenzhen city, China. Plant Soil Environment. 54(8): 341-346.

Tabatabai, M.A., 1982. In A.L. Page (eds.) Methods of Soil Analysis, Part 2, Soil Enzymes, American Society. Agron, Madison. 903-948.

Tabatabai, M.A., and Bremner, J.M. 1970. Arylsulfatase activity in soils. Soil Science Society of America Proc. 34:225-229.

Tarafdar, J.C., and Chhonkar, P.K. 1978. Status of phosphatases in root soil interface of leguminous and nonleguminous crops. Zeitschriftfur Pflanzeneraehr Bodenkunde. 141: 347351.

Tripathi, K, P., Harsh, L.N., Rao, A.V. and Praveen-kumar. 2006. Impact of Polluted. Underground Water from Seepage of Industrial Effluents on Soil Properties and Growth of Acacia Senegal. Journal of the Indian Society 
of Soil Science. 54(1): 101- 105.

Turner, B.L., 2010. Variation in $\mathrm{pH}$ optima of hydrolytic enzyme activities in tropical rain forest soils. Applied and Environmental Microbiology. 76(19): 6485-6493.

Vandana, L.J., 2012. Urease and Phosphomonoesterase activities in soiltheir distribution kinetics and influence of management practices on their activity. Ph $D$ Thesis. Acharya N G
Ranga Agricultural University, Hyderabad

Wallenstein, M., Allison, S. D., Ernakovich, J., Steinweg, J. M and Sinsabaugh, R. 2011. Controls on the temperature sensitivity of soil enzymes: A Key Driver of in Situ Enzyme activity Rates. In Shukla and A. Varma (eds.), Soil Enzymology, soil biology 22, Springer Verlag, Berlin, Heidelberg. 245-258.

\section{How to cite this article:}

Pavani, G., P. Chandrasekhar Rao, G. Padmaja and Naveen Kumar, B. 2017. Effect of Soil Temperature, Moisture and $\mathrm{pH}$ on Soil L-glutaminase Activity. Int.J.Curr.Microbiol.App.Sci. 6(8): 3081-3087. doi: https://doi.org/10.20546/ijcmas.2017.608.369 